\title{
Hyaluronic acid increases tendon derived (1) CrossMark cell viability and collagen type I expression in vitro: Comparative study of four different Hyaluronic acid preparations by molecular weight
}

\author{
Leonardo Osti ${ }^{1 *}$, Martina Berardocco ${ }^{2}$, Viviana di Giacomo ${ }^{3}$, Graziella Di Bernardo ${ }^{4}$, Francesco Oliva ${ }^{5}$ \\ and Anna C. Berardi $i^{*}$
}

\begin{abstract}
Background: Hyaluronic Acid (HA) has been already approved by Food and Drug Administration (FDA) for osteoarthritis $(\mathrm{OA})$, while its use in the treatment of tendinopathy is still debated. The aim of this study was to evaluate in human rotator cuff tendon derived cells the effects of four different HA on cell viability, proliferation, apoptosis and the expression of collagen type I and collagen type III.

Methods: An in vitro model was developed on human tendon derived cells from rotator cuff tears to study the effects of four different HA preparations (Ps) (sodium hyaluronate MW: 500-730 KDa - Hyalgan ${ }^{\oplus} 1000 \mathrm{kDa}$ Artrosulfur HA $A^{\oplus}, 1600$ KDa Hyalubrix ${ }^{\oplus}$ and 2200 KDa Synolis-VA ${ }^{\oplus}$ ) at various concentrations. Tendon derived cells morphology were evaluated after 0,7 and $14 \mathrm{~d}$ of culture. Viability, proliferation, apoptosis were evaluated after 0 , 24 and $48 \mathrm{~h}$ of culture. The expression and deposition of collagen type I and collagen type III were evaluated after 1,7 and $14 \mathrm{~d}$ of culture.

Results: All HAPs tested increased viability and proliferation, in dose dependent manner. HAPs already reduce apoptosis at $24 \mathrm{~h}$ compared to control cells (without HAPs). Furthermore, HAPs stimulated the synthesis of collagen type I in a dose dependent fashion over $14 \mathrm{~d}$, without increase in collagen type III; moreover, in the presence of Synolis-VA ${ }^{\oplus}$ the expression and deposition of collagen type I was significantly higher as compare with the other HAPS.
\end{abstract}

Conclusions: HAPs enhanced viability, proliferation and expression of collagen type I in tendon derived cells.

Keywords: Hyaluronic acid, Tendinopathy, Human tendon derived cells, Rotator cuff tendons, Shoulder

\section{Background}

Non-traumatic rotator cuff tears are the most common shoulder joint disease, and have age-associated incidence, since they are favored by the co-presence of metabolic diseases such as diabetes, thyroid disorders and hypercholesterolemia [1-4]. Conservative treatment of tendinopathies has been increasingly supported by scientific evidence over the last twenty year [5]. Despite decades of study for $\mathrm{HA}$ in the conservative treatment of osteoarthritis [6], poor evidence is present in the

\footnotetext{
*Correspondence: leonardoosti@yahoo.com; annacberardi@yahoo.it

'Unit of Arthoscopy and Sports Trauma Surgery, Hesperia Hospital, Modena, Italy ${ }^{2}$ U.O.C. of Immunohaematology and Transfusion Medicine, Laboratory of Stem Cells, Spirito Santo Hospital, via Fonte Romana 8, 65125 Pescara, Italy Full list of author information is available at the end of the article
}

literature about the indication of this drug for tendinopathies [7]. During tendinopathy and tendon acute rupture has been reported an higher incidence of tenocyte apoptosis and decreased collagen synthesis [8]. Failure of the healing response may occur in geneticallypredisposed patients, decreasing the resistance of tendon structures to mechanical load, resulting eventually in tendinopathy, or a tendon tear $[4,9,10]$.

Hyaluronic acid (HA) (or "hyaluronan", or "sodium hyaluronate preparation") is a high molecular weight glycosaminiglycan consists of the repetition of a disaccharide unit of an $\mathrm{N}$-acetyl-glucosamine and a $\beta$-glucuronic acid [11]. Its most important physicochemical properties are its capacity to retain water, having a very high hydration ratio, 
and its visco-elasticity. These two properties are, however, interdependent. Changes in HA concentrations within the extracellular matrix modulate a variety of cellular functions, such as cell migration [12, 13], adhesion $[14,15]$, and proliferation [16-18]. Several important medical applications of HA have been discovered for joints degeneration [7]. Additionally, high local concentration of HA causes release of endogenous growth factors and stimulates cell-cell interaction, resulting in faster cell proliferation during early stages of in vitro culture. Additional effects reported in clinical animal studies are related to an accelerated healing process in the tendons after repair, and decreased scar formation within the tendons. There has been a lack of specific studies on human shoulder derived cells. Much of the study, has been limited by the lack of the exact phenotype of the tendon derive cells, moreover, the pattern of gene expression is consistent with the presence of mixed population. [19]. Clinical studies in patients with rotator cuff disease ranging from tendinopathy to rotator cuff tears detected a positive influence on the reduction of pain and improved function with no consistent sideeffects recorded. Despite the increased awareness of the effective role of HA in regenerative medicine, the therapeutic use of HA for tendinopathies has been poorly studied on human tenocytes in vitro.

In this study, was evaluated the effect of four different HAPs by molecular weight on viability, metabolic activity, apoptosis and collagen type I and collagen type III expression on human rotator cuff tendon tears derived cells.

\section{Methods}

All the procedures described in this investigation were approved by the Ethical Committee of Rome Tor Vergata University. All the patients gave written informed consent to be included in the present study. Tendon samples were harvested from healthy area close to degenerative supraspinatus tendons tear area biopsy specimen in 10 patients were operated arthroscopically for shoulder rotator cuff repair, with a mean age of $63,6 \pm 6,9$ years. Trauma history, heavy smoking habit or systemic conditions such as thyroid disorders, diabetes, gynecological condition, neoplasia, rheumatic diseases, and any previous or concomitant rotator cuff disease were considered exclusion criteria.

\section{Tendon cell cultures}

Primary human tendon derived cell cultures were established as previously described [20]. In brief, cells were isolated from tissue sample by washing several times with phosphate buffered saline Dulbecco's W/O Ca and $\mathrm{Mg}$ (PBS) + $1 \%$ penicillin/streptomycin (Invitrogen, Life Technologies, Carlsbad, CA, USA). Small pieces of fresh tendon isolated were carefully dissected and mechanically disaggregated with the aid of fine watchmaker forceps to maximize the interface between tissue and medium. Finally, the tendons were immediately placed on Petri dishes of $60 \mathrm{~mm}$ in diameter (Greiner CELLSTAR dish, Sigma- Aldrich, Saint Louis, MO, USA), containing $5 \mathrm{~mL}$ of $\alpha$-MEM supplemented with $20 \%$ heatinactivated foetal calf serum (FCS) and $1 \%$ L-glutamine and $1 \%$ penicillin/streptomycin (Gibco, Invitrogen, Life Technologies) at $37{ }^{\circ} \mathrm{C}$ in $5 \% \mathrm{CO}_{2}$ and air with a change medium every 2-3 d. Tenocytes were then harvested by StemPro Accutase (Life technologies Carlsbad, CA, USA), and centrifugated at $1,500 \mathrm{rpm}$ for $5 \mathrm{~min}$ when the cells migrated out of tendon pieces and reached $60-80 \%$ of confluence (19 day). Collected tendon derived cells were immediately used for culture to avoid phenotype drift with further in vitro passages [21]. The phenotype of the tendon derived cells had not demonstrated significant drift as evidence by the gene expression pattern by assessing the expression of gene for scleraxis and genes for collagens $\alpha 1(\mathrm{I}), \alpha 2(\mathrm{I})$ and $\alpha 1$ (III) in real-time PCR assays with specific primers (data not shown).

\section{Tenocyte viability and proliferation}

In vitro proliferation was determined by the Alamar Blue assay. This test was used to measure the metabolism rate of the cells. The tendon derived cells were seeded with $5 \times 10^{3}$ vital cells per well in a 96-well plate (Greiner CELLSTAR dish, Sigma-Aldrich), and in triplicates in $100 \mu \mathrm{l}$ of $\alpha$-MEM supplemented with $10 \%$ FCS . Cells were cultured as previous described [20]. Briefly, after $24 \mathrm{~h}$, cultured cells were exposed to 4 different hyaluronic acid: Hyalgan MW 500-730 KDa, Artrosulfur $\mathrm{HA}^{\circ} \mathrm{MW} 1000$, Hyalubrix ${ }^{\odot}$ MW $1600 \mathrm{KDa}$, Synolis-VA ${ }^{\circ}$ MW $2200 \mathrm{KDa}$, their features are shown in Table 1 . Three different doses of Hyalgan or Artrosulfur $\mathrm{HA}^{\circ}(250 \mu \mathrm{g} / \mathrm{ml}, 500 \mu \mathrm{g} / \mathrm{ml}$ and $1000 \mu \mathrm{g} / \mathrm{ml})$, one doses of Hyalubrix ${ }^{\circ}$ or Synolis-VA ${ }^{\circ}$ $(1000 \mu \mathrm{g} / \mathrm{ml})$. HAPs were dissolved in the same culture media used for the entire experiments ( $\alpha$-MEM supplemented with $10 \%$ FCS) and the Ph was adjusted to 7 . Untreated cells were used as control. All the cells (HAPs treated and untreated) were cultured in $1 \mathrm{ml}$ of medium. Alamar blue dye test (Serotec, Oxford, UK) was performed to assess cell viability after 0,24 , and $48 \mathrm{~h}$ of culture, as previous described [16]. The absorbance was read spectrophotometrically at 570 and $600 \mathrm{~nm}$ wavelengths by MicroPlate reader (BioRad, Hercules, CA). The results, obtained as optical density (OD) data, were processed following manufacturer's instructions and expressed as reduction percentage. The calculation of the of the percentage of alamar blue reduction is as follows according to the manufacture's protocol: 
Table 1 Features of Hyaluronic Acids preparations tested

\begin{tabular}{|c|c|c|c|c|}
\hline $\begin{array}{l}\text { Commecial } \\
\text { Name }\end{array}$ & Hyalgan ${ }^{\oplus}$ & Artrosulfur $\mathrm{HA}^{\oplus}$ & Hyalubrix $^{\circledast}$ & Synolis-VA ${ }^{\oplus}$ \\
\hline Active Substance & Linear Sodium Hyaluronate & $\begin{array}{l}\text { Linear Sodium } \\
\text { Hyaluronate }\end{array}$ & Linear Sodium Hyaluronate & $\begin{array}{l}\text { Linear Sodium Hyaluronate + Sorbitol (4 \%) } \\
\text { (limits the HA degradation) }\end{array}$ \\
\hline Molecular Weight & $600-730 \mathrm{KDa}$ & $1000 \mathrm{KDa}$ & $1600 \mathrm{KDa}$ & $2000 \mathrm{KDa}$ \\
\hline Source & Rooster Combs & $\begin{array}{l}\text { Bacterial } \\
\text { Fermentation }\end{array}$ & Bacterial Fermentation & Bacterial Fermentation \\
\hline \multirow[t]{3}{*}{ Doses Tested } & $250 \mu \mathrm{g} / \mathrm{ml}$ & $250 \mu \mathrm{g} / \mathrm{ml}$ & $1000 \mu \mathrm{g} / \mathrm{ml}$ & $1000 \mu \mathrm{g} / \mathrm{ml}$ \\
\hline & $500 \mu \mathrm{g} / \mathrm{ml}$ & $500 \mu \mathrm{g} / \mathrm{ml}$ & & \\
\hline & $1000 \mu \mathrm{g} / \mathrm{ml}$ & $1000 \mu \mathrm{g} / \mathrm{ml}$ & & \\
\hline Manufacturer & $\begin{array}{l}\text { Fidia Farmaceutici s.p.a., } \\
\text { Abano Terme (PD), Italy }\end{array}$ & $\begin{array}{l}\text { Laborests.p.a., } \\
\text { Nerviano (MI), Italy }\end{array}$ & $\begin{array}{l}\text { Fidia Farmaceutici s.p.a. } \\
\text { Abano Terme (PD), Italy }\end{array}$ & Anteis s.a., Geneva, Switzerland \\
\hline
\end{tabular}

$$
\begin{aligned}
& \frac{\left(\varepsilon_{\mathrm{ox}} \lambda_{2}\right)\left(\mathrm{A} \lambda_{1}\right)-\left(\varepsilon_{\mathrm{ox}} \lambda_{1}\right)\left(\mathrm{A} \lambda_{2}\right) \text { of test agent dilution }}{\left(\varepsilon_{\mathrm{red}} \lambda_{1}\right)\left(\mathrm{A}^{\prime} \lambda_{2}\right)-\left(\varepsilon_{\mathrm{red}} \lambda_{2}\right)\left(\mathrm{A}^{\prime} \lambda_{1}\right) \text { of untreated positive growth control }} \\
& \times 100
\end{aligned}
$$

In the formula $\varepsilon \lambda_{1}$ and $\varepsilon \lambda_{2}$ are constant representing the molar extinction coefficient of alamar blue at $540 \mathrm{~nm}$ and $630 \mathrm{~nm}$, respectively, in the oxidized $\left(\varepsilon_{\text {ox }}\right)$ and the reduced $\left(\varepsilon_{\text {red }}\right)$ forms. $A \lambda_{1}$ and $A \lambda_{2}$ represent absorbance of test wells at $540 \mathrm{~nm}$ and $630 \mathrm{~nm}$, respectively. $\mathrm{A}^{\prime} \lambda_{1}$ and $\mathrm{A}^{\prime} \lambda_{2}$ represent absorbance of negative control wells at 540 and $630 \mathrm{~nm}$, respectively. The values of \% alamar blue reduction were corrected for background values of negative controls containing medium without cells.

Finally, in parallel trypan blue exclusion assay was performed. The tendon derived cells were seeded with $10^{4}$ vital cells per well in a 24-well plate (Greiner CELLSTAR dish, Sigma-Aldrich), and in triplicates in $1 \mathrm{ml}$ of $\alpha$-MEM supplemented with $10 \%$ FCS. After 0, 24 and 48 h the cultures were detached, collected and counted (Nikon Instruments INC., Melville, NY, USA) in the Burker chamber with vital dye Trypan Blue (Stem Cells Technologies, Vancouver, Canada) to evaluate cell viability.

\section{Apoptosis induction}

Hydrogen peroxide $\left(\mathrm{H}_{2} \mathrm{O}_{2}\right)$ was used as an inducer of apoptosis as previously described [22]. The tendon derived cells were seeded with $10^{5}$ vital cells per well in a 6-well plate in $4 \mathrm{ml}$ of $\alpha$-MEM supplemented with $10 \%$ FCS. After $24 \mathrm{~h}$, the medium was removed, and the cultured cells were treated with $\mathrm{H}_{2} \mathrm{O}_{2}(2 \mathrm{mM})$ in $\alpha$-MEM and $10 \%$ FCS with or without Hyalgan ${ }^{\circ}$, Artrosulfur $\mathrm{HA}^{\oplus}$, Hyalubrix ${ }^{\oplus}$ and Synolis-VA ${ }^{\odot}(1000 \mu \mathrm{g} / \mathrm{ml})$ for a further $24 \mathrm{~h}$. A negative control was prepared by incubating cells in the absence of both inducing agent and HAPs. The PE Annexin V/Dead Cell Apoptosis Kit with SYTOX ${ }^{\odot}$ Green for Flow Cytometry (Invitrogen, Life Technologies) was used to detect apoptosis by flow cytometry, cells were harvested, and processed according to the manufacturer's instruction. This product detects the externalization of phosphatidylserine in apoptotic cells using recombinant annexin $\mathrm{V}$ conjugated to the orange fluorescent phycobiliprotein R-PE, and dead cells using SYTOX ${ }^{\bullet}$ Green nucleic acid stain. After treatment with both probes, apoptotic cells show orange fluorescence, dead cells show green fluorescence, and live cells show little or no fluorescence. Fluorescence-activated cell sorting analysis was carried out using a FC500 flow cytometer (FL1 and FL3 detector in a log mode) using the CXP analysis software (Beckmann Coulter, FL, USA).

\section{Immunofluorescence staining}

The tendon derived cells were seeded with $5 \times 10^{3}$ vital cells per well in a 2-well chamber slides (Thermo Fisher Scientific, Inc., Rochester, NY, USA), in triplicates and cultured as previous described [23]. After 1, 7 and $14 \mathrm{~d}$ of culture the tendon derived cells were fixed with pure acetone for $10 \mathrm{~min}$ at $-20{ }^{\circ} \mathrm{C}$. Then, washed a few $\mathrm{mi}-$ nutes with PBS. Cells were incubated for $30 \mathrm{~min}$ at room temperature with PBS containing $5 \%$ of Bovine Serum Albumin (BSA) (Kedrion Group S.P.A., Lucca, Italy) for protein blockage. Primary antibodies for Anti-type I (1:2000), Anti-type III collagen molecules (1:500) (Sigma-Aldrich), and secondary antibodies fluorochrome were diluted in PBS containing $5 \%$ BSA. Cells were incubated overnight at $4{ }^{\circ} \mathrm{C}$ with primary antibodies, $1 \mathrm{~h}$ with the appropriate secondary antibody fluorochrome at room temperature and then washed a few times with PBS containing $5 \%$ BSA. Molecule's staining Alexa Fluor 488 (Life Tecnologies) was used for type I collagen and Alexa Fluor 568 (Life Tecnologies) for type III collagen. After washing with PBS plus $5 \%$ BSA, slides were mounted with $25 \mu \mathrm{L}$ VECTASHIELD ${ }^{\circ}$ Hard Set Mounting Medium and then were examinated with ECLIPSE Ti-U inverted, fluorescent microscope (Nikon Instruments INC., 
Melville, NY, USA). For image analysis all digital images were captured with NIS-Elements Imaging Software (Nikon Instruments INC.). As previously described [23, 24], slides were examined independently by two experienced operator and one researcher, with a double-blind method. The total fluorescence intensity of the area $\geq 10$ frames from each slides was determined. The intensity level was normalized with the control cells untreated. Fully automated image analysis improve the accuracy of detection and categorization of collagen staining, making this technique more sensitive, specific and thus suitable for use in quality assurance results.

\section{Statistical analysis}

Data are typical results from a minimum of three replicated independent experiments and are expressed as mean \pm SD. Comparison of individual treatment was conducted using Student's $t$ test. Statistical significance in comparison with the corresponding control values was indicated by $* P<0.05$ versus control.

\section{Results}

Tendon derived cells viability

Tendon derived cells morphology was evaluated under a light microscope at 0,7 and $14 \mathrm{~d}$. The cells maintained their normal, bipolar, spindle shape and cell processes, during the whole study period for each of the sets of culture conditions; cellular morphology remained unaltered for up to $14 \mathrm{~d}$ in all the experimental groups (Fig. 1a). Results from the trypan blue exclusion assay showed that none of the HAPs reduced cell viability (Fig. 1b). After $48 \mathrm{~h}$ of exposure, living cells are in similar numbers when exposed to HAPs compared to the control. Metabolic tests provide some information concerning the activity of cells (Fig. 1c). Alamar blue confirmed an increase in the metabolic activity of tendon derived cells for all the HAPs utilized, when compared to untreated cells (Fig. 1c). In particular, all HAPs induced cell-activity most effectively at $1000 \mu \mathrm{g} / \mathrm{ml}$ (Fig. 1c, Table 2). The highest increase was obtained at $48 \mathrm{~h}$ for all the HA treatments. However, as reported in Fig. 1c, there are no significant statistical differences between all the various HAPs.

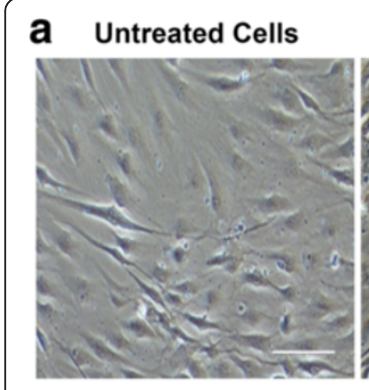

b

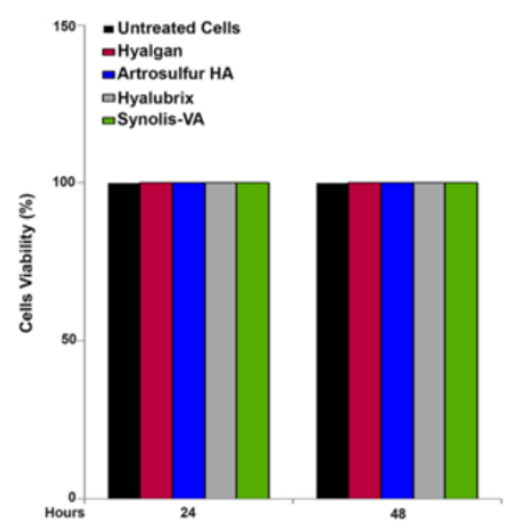

C

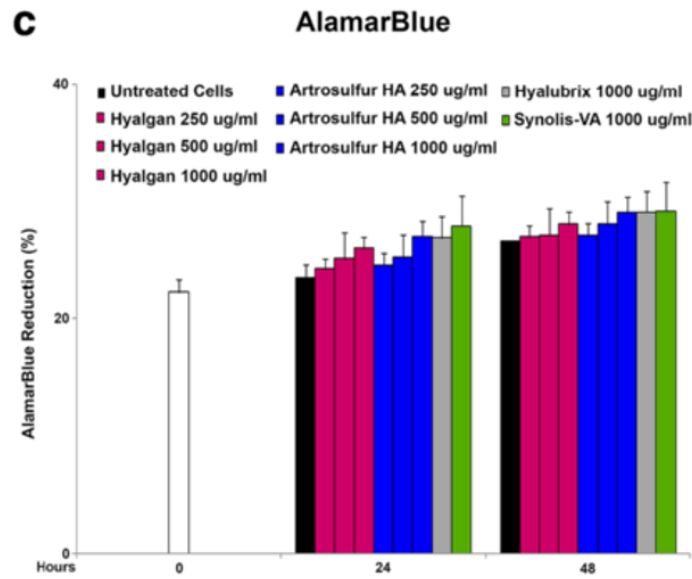

Fig. 1 Effects of Hyalgan ${ }^{\oplus}$, Artrosulfur $H A^{\oplus}, H y a l u b r i x^{\oplus}$ and Synolis-VA ${ }^{\oplus}$ on morphologic change cell viability and cell metabolic activity. Tendon derived cells were treated with different concentrations of Hyalgan, Artrosulfur HA ${ }^{\circledR}$, Hyalubrix ${ }^{\circledR}$ and Synolis-VA ${ }^{\circledR}$ for different time periods. a. after treatment for $14 \mathrm{~d}$ the morphology of the cells treated with all the HAPs was photographed (1000ug/ml). Magnification, $\times 100$. $\mathbf{b}$. Absolute number of live cells was calculated using trypan blue exclusion. c. Cell metabolic activity was evaluated with the Alamar Blue method. All tests and determinations were repeated in triplicate. The metabolic activity rate was calculated by subtracting the background OD value (complete culture medium without cells) from the OD value from each test well (see materials and methods section). Hyalgan ${ }^{\circledast}$, Artrosulfur HA ${ }^{\oplus}$, Hyalubrix $^{\circledR}$, Synolis-VA ${ }^{\circledR}$ increased cell activity in a concentration-dependent pattern and with regard to time. No statistically significant difference were observed from control according to Student's $t$ test 
Table 2 Summary of results

\begin{tabular}{|c|c|c|c|}
\hline \multicolumn{4}{|l|}{ METABOLIC ACTIVITY } \\
\hline Cells & $\mathrm{Oh}$ & $24 \mathrm{~h}$ & $48 \mathrm{~h}$ \\
\hline Untreated & $22,25 \% \pm 1,1 \%$ & $23,18 \% \pm 1,3 \%$ & $26,69 \% \pm 0,1 \%$ \\
\hline Hyalgan ${ }^{\circledast} 250 \mu \mathrm{g} / \mathrm{ml}$ & & $23,68 \% \pm 0,9 \%$ & $26,92 \% \pm 1,4 \%$ \\
\hline Hyalgan $^{\oplus} 500 \mu \mathrm{g} / \mathrm{ml}$ & & $25,37 \% \pm 2,2 \%$ & $27,14 \% \pm 1,9 \%$ \\
\hline Hyalgan ${ }^{\circledast} 1000 \mu \mathrm{g} / \mathrm{ml}$ & & $25,54 \% \pm 1,2 \%$ & $27,71 \% \pm 1,3 \%$ \\
\hline Artrosulfur HA $\otimes^{\oplus} 250 \mu \mathrm{g} / \mathrm{ml}$ & & $24,13 \% \pm 1,1 \%$ & $27,16 \% \pm 1 \%$ \\
\hline Artrosulfur HA $\odot 500 \mu \mathrm{g} / \mathrm{ml}$ & & $25,47 \% \pm 1,8 \%$ & $27,7 \% \pm 1,7 \%$ \\
\hline Artrosulfur HA ${ }^{\otimes} 1000 \mu \mathrm{g} / \mathrm{ml}$ & & $26,9 \% \pm 1,5 \%$ & $28,55 \% \pm 1,4 \%$ \\
\hline Hyalubrix ${ }^{\otimes} 1000 \mu \mathrm{g} / \mathrm{ml}$ & & $26,85 \% \pm 1,9 \%$ & $28,56 \% \pm 1,9 \%$ \\
\hline Sinolis -VA $1000 \mu \mathrm{g} / \mathrm{ml}$ & & $27,44 \% \pm 2,2 \%$ & $28,58 \% \pm 2,1 \%$ \\
\hline \multicolumn{4}{|l|}{ APOPTOSIS } \\
\hline Cells & Live cells & Early & Late \\
\hline Proliferant control & $91,2 \% \pm 0,2 \%$ & $1,8 \% \pm 0,2 \%$ & $4 \% \pm 0,8 \%$ \\
\hline Apoptotic control & $20,5 \% \pm 0,7 \%$ & $10,9 \% \pm 0,1 \%$ & $66,8 \% \pm 0,1 \%$ \\
\hline Hyalgan ${ }^{\circledast} 1000 \mu \mathrm{g} / \mathrm{ml}$ & $31,2 \% \pm 9,4 \%$ & $12,4 \% \pm 2,5 \%$ & $54,4 \% \pm 7,1 \%$ \\
\hline Artrosulfur HA ${ }^{\oplus} 1000 \mu \mathrm{g} / \mathrm{ml}$ & $20,7 \% \pm 8 \%$ & $9,2 \% \pm 0,2 \%$ & $66,8 \% \pm 0,7 \%$ \\
\hline Hyalubrix ${ }^{\otimes} 1000 \mu \mathrm{g} / \mathrm{ml}$ & $34,9 \% \pm 6,7 \%$ & $11,2 \% \pm 1,3 \%$ & $52,4 \% \pm 5,3 \%$ \\
\hline Sinolis -VA ${ }^{\oplus} 1000 \mu \mathrm{g} / \mathrm{ml}$ & $31,3 \% \pm 3,5 \%$ & $12 \% \pm 1,7 \%$ & $55 \% \pm 1,9 \%$ \\
\hline \multicolumn{4}{|l|}{ MEAN GREEN INTENSITY } \\
\hline Cells & Day 0 & Day 7 & Day 14 \\
\hline Untreated & 0,5 & $4,2 \pm 0,9$ & $8,6 \pm 1$ \\
\hline Hyalgan ${ }^{\circledast} 1000 \mu \mathrm{g} / \mathrm{ml}$ & & $6,7 \pm 1,1$ & $12,3 \pm 1,3$ \\
\hline Artrosulfur $\mathrm{HA}^{\otimes} 1000 \mu \mathrm{g} / \mathrm{ml}$ & & $6,4 \pm 1,5$ & $12,4 \pm 1,3$ \\
\hline Hyalubrix $1000 \mu \mathrm{g} / \mathrm{ml}$ & & $8,9 \pm 2,2$ & $10,9 \pm 2,1$ \\
\hline Sinolis -VA ${ }^{\oplus} 1000 \mu \mathrm{g} / \mathrm{ml}$ & & $8,6 \pm 2,5$ & $16,1 \pm 3$ \\
\hline
\end{tabular}

\section{Apoptosis induction}

To verify whether or not they counteracted apoptosis in tendon derived cells, the Annexin $\mathrm{V}$ experiment was performed. Cells were plated and $\mathrm{H}_{2} \mathrm{O}_{2}$ induction was performed for $24 \mathrm{~h}$ to induce apoptosis. Concurrently, tendon derived cells were separately exposed (or not, for the untreated sample) to Hyalgan ${ }^{\odot}$, Artrosulfur $\mathrm{HA}^{\oplus}$, Hyalubrix $^{\oplus}$, and Synolis-VA ${ }^{\odot}(1000 \mu \mathrm{g} / \mathrm{ml})$. Staining cells simultaneously with PE-Annexin V (red fluorescence) and the non-vital dye, Sytox Green (green fluorescence), allowed, using bivariate analysis, discrimination between intact cells (Annexix $\mathrm{V}^{-}$Sytox Green $^{-}$), early apoptotic (Annexix $\mathrm{V}^{+}$Sytox Green ${ }^{-}$) and late apoptotic (Annexix $\mathrm{V}^{+}$Sytox Green ${ }^{+}$) and necrotic cells (Annexix $\mathrm{V}^{-}$Sytox Green $^{+}$) (Fig. 2a). The treatment of tendon derived cells with Hyalgan ${ }^{\oplus}$, Artrosulfur $\mathrm{HA}^{\oplus}$, Hyalubrix ${ }^{\oplus}$, or Synolis$\mathrm{VA}^{\oplus}$ (all at $1000 \mu \mathrm{g} / \mathrm{ml}$ ) caused a sizable decrease in apoptosis, as clearly shown in Fig. 2b. The percentage of vital cells, at $24 \mathrm{~h}$ following Hyalgan ${ }^{\bullet}$ Artrosulfur $\mathrm{HA}^{\oplus}$, Hyalubrix $^{\oplus}$, or Synolis-VA ${ }^{\oplus}$ exposure, increased compared to the control $(33.14,24.01,36.31,33.04$ and
$22.25 \%$ respectively) (Annexix $\mathrm{V}^{-}$, Sytox green ${ }^{-}$; bottom left quadrant) (Fig. 2c, Table 2).

\section{Immunofluorescence staining}

Next, we determined and measured the type of collagen deposited by tendon derived cells after stimulation with Hyalgan $^{\oplus}$, Artrosulfur $\mathrm{HA}^{\oplus}$, Hyalubrix ${ }^{\oplus}$, or Synolis-VA ${ }^{\oplus}$. Collagen accumulation was evaluated by immunofluorescent staining of cells cultured on chamber slides. Furthermore, the expression of collagen type I was higher in Synolis-VA ${ }^{\oplus}$ than in the presence of $\operatorname{Hyalgan}^{\odot}$, Artrosulfur $\mathrm{HA}^{\oplus}$, or Hyalubrix ${ }^{\oplus}$, and was significantly higher compared to untreated cells used as a control (Fig. 2a, b). In detail, immunofluorescent staining at day 7 only revealed production of collagen type I from the tendon derived cells in intracytoplasmic staining (Fig. 3a). Moreover, at day 14 expression and production of Collagen type I had increased in the Hyalgan ${ }^{\odot}$, Artrosulfur $\mathrm{HA}^{\oplus}$, Hyalubrix ${ }^{\circ}$ and Synolis$\mathrm{VA}^{\oplus}$ (Fig. 3a, b). Moreover, Synolis-VA ${ }^{\oplus}$ induced the most significant expression of collagen type I after $14 \mathrm{~d}$ 


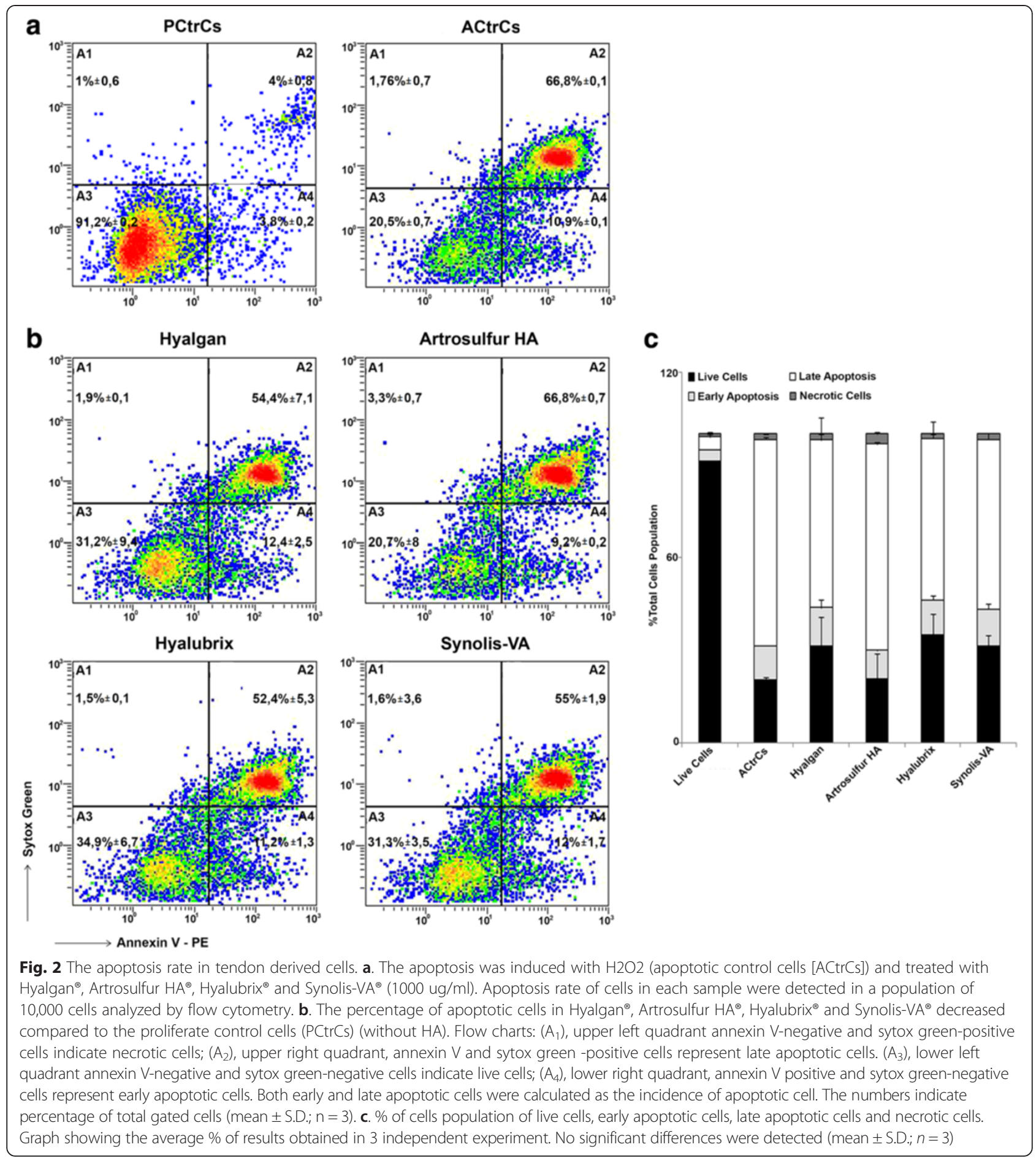

(Fig. 3, Table 2). Collagen type III was not found to be present in any culture conditions (data not shown).

\section{Discussion}

These results suggest a binary role for HA on tendon cells - directly, on tendon derived cells metabolic activity, and on tenocyte Collagen type I production. It was highlighted that Hyalgan, Artrosulfur $\mathrm{HA}^{\circ}$, Hyalubrix ${ }^{\circ}$ and Synolis- $\mathrm{VA}^{\circ}$ regulate cell activity of tendon derived cells. All HAPs increased cell-metabolic activity and most effectively at $1000 \mu \mathrm{g} / \mathrm{ml}$ and at $48 \mathrm{~h}$ (Fig. 1c). HA modulate a number of biological process including cell apoptosis. The results show a decrease rate of the apoptosis when the tendon derived cells were exposed to the 


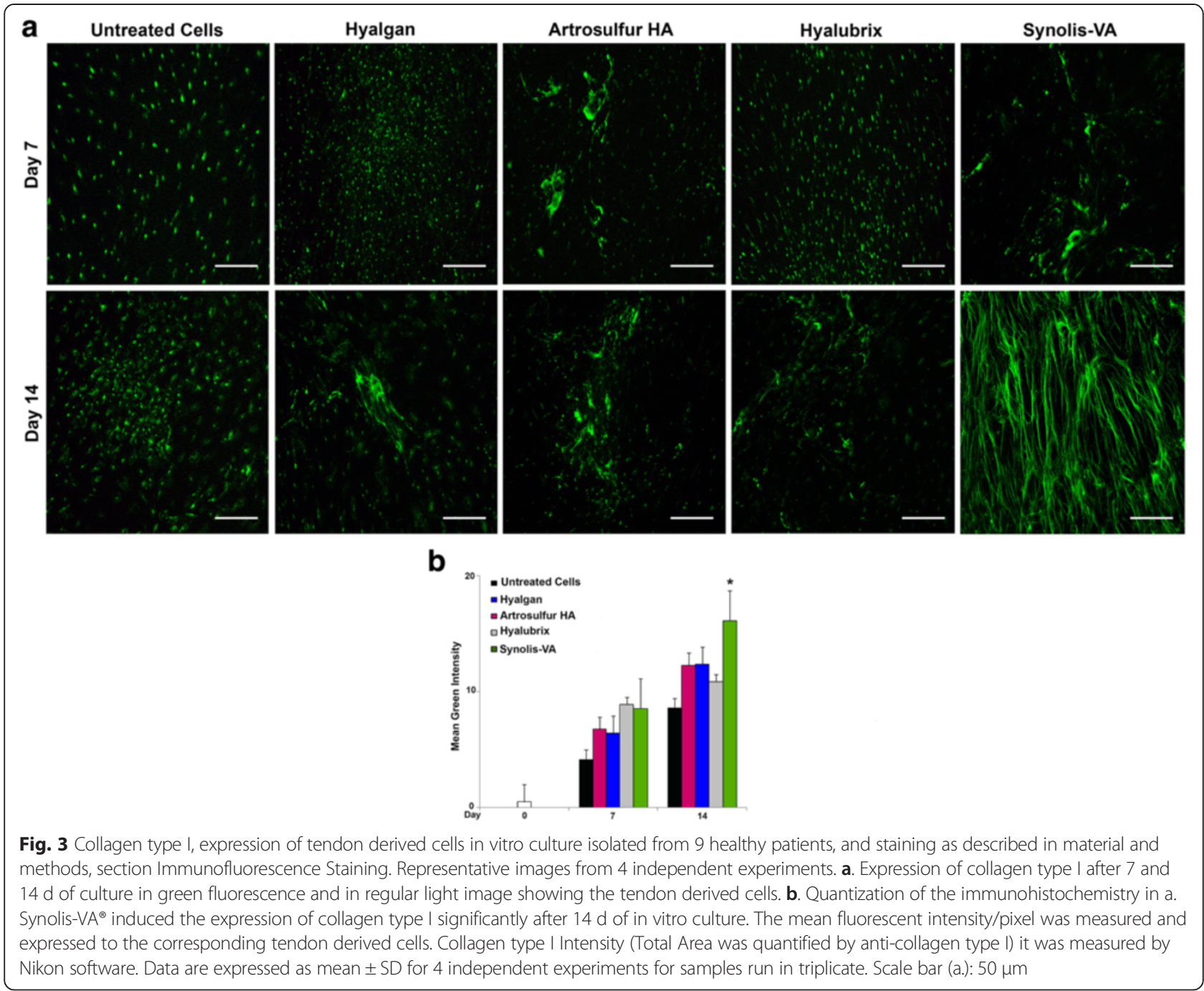

HAPs. Collagen metabolism has been reported to be affected by HA $[25,26]$. HA stimulated the synthesis of collagen type I, in a dose dependent manner over $14 \mathrm{~d}$. This increase in expression leads to collagen synthesis and accumulation. It should be noted that Synolis-VA ${ }^{\circ}$ induced the most significant expression of collagen type I at $14 \mathrm{~d}$ of culture. In contrast, no HAPs induced any expression of collagen type III, which is normally less abundant in tendons, and only increases in concentration during the early phase of remodeling [27] and in tendinopathy $[20,28]$. The lack of collagen type III production under HA stress should be considered a protective factor for tendons. The results obtained are consistent with a previous study of Yamada and coworkers, even if a different methods focused directly on the collagen type I and III proteins was used [29].

Considering the results of this study, the three different molecular weight of HAPs tested seems not exert any effects on tendon derived cells in vitro, while is clear the essential importance of the concentrations and of the timing of exposure. The most significant expression of collagen type I at $14 \mathrm{~d}$ of culture of Synolis-VA ${ }^{\circ}$ can be explained to the presence of Sorbitol (4\%) that limits the HA degradation, allowing an higher local concentration of the drug. Translating these considerations in the clinical practice, HA are effectives on human tenocytes and extracellular matrix of rotator cuff, with no essential differences among HA available in the market. There are many biological questions that remain to be answered, and translational factors to resolve. Although, this in vitro model shows some role played from HA on tendon derived cells, the study have some limitations. First of all, probably these results cannot be generalized for other tendon derived cells from other sources; furthermore in vitro environment, rich of nutrients and oxygen is very different from the diseased environment. The complexity of the extracellular matrix of tendons and its relationship with tenocytes during physiological homeostasis, disease and 
healing process, attest that is reductive to investigate only the effect of HAPs on collagen type I and III. As soon as possible there is need to widen the knowledge of the effects of HAPs on the main proteins of the extracellular matrix of tendons.

Despite we tested the three different molecular weight HA, perhaps more HAPs and different concentration need to be tested in the same way we did to confirm which should have the best in vitro results.

Obviously, it is advocate randomized control studies on the use of HA in the conservative treatment of tendinopathy and in selected patients with rotator cuff tears, in order to understand and clarify best timing, doses, intervals of injections and, finally, full clinical confirmation of effectiveness.

\section{Conclusion}

In conclusion, HAPs in dose dependent manner but not related to the molecular weight, induces increase of cells activities, decrease of apoptosis of tendon derived cells Collagen type I protein secretion. Taken together, these results strengthen a physiological role of $\mathrm{HA}$ in the homeostasis of tendons and has implications for regenerative medicine.

\section{Competing interests}

The authors declare that they have no competing interests.

\section{Authors' contributions}

$\mathrm{LO}$ and ACB made substantial contributions to the conception and design of this manuscript, data acquisition, analysis and interpretation and the drafting of the manuscript. MB carried out the Tendon cell cultures, Tendon derived cells viability and metabolic activity. VdG Apoptosis analyses. GDB participated in tendon derived cells culture. ACB conceived the study and participated in its design and coordination. FO critically revised the manuscript for important intellectual content, and gave the final approval of the version to be published. All authors read and approved the final manuscript.

\section{Authors' information}

Not applicable.

\section{Acknowledgements}

The laboratory "Stem Cells" is supported by Fondazione PCFF ONLUS. The authors also wish to thank Blood Donors Association FIDAS Pescara.

\section{Author details}

${ }^{1}$ Unit of Arthoscopy and Sports Trauma Surgery, Hesperia Hospital, Modena, Italy. ${ }^{2}$ U.O.C. of Immunohaematology and Transfusion Medicine, Laboratory of Stem Cells, Spirito Santo Hospital, via Fonte Romana 8, 65125 Pescara, Italy. ${ }^{3}$ Department of Pharmacy, University G. d'Annunzio, Chieti, Italy. ${ }^{4}$ U.O.C. of Immunohaematology and Transfusion Medicine, Santo Spirito Hospital, Pescara, Italy. ${ }^{5}$ Department of Orthopedics and Traumatology, University of Rome "Tor Vergata" School of Medicine, Rome, Italy.

Received: 10 June 2015 Accepted: 24 September 2015

Published online: 06 October 2015

\section{References}

1. Oliva F, Osti L, Padulo J, Maffulli N. Epidemiology of the rotator cuff tears: a new incidence related to thyroid disease. Muscles Ligaments Tendons J. 2014;4(3):309-14

2. Osti L, Rizzello G, Panascì M, Denaro V, Maffulli N. Full thickness tears: retaining the cuff. Sports Med Arthosc. 2011;19(4):409-19.
3. Oliva F, Berardi AC, Misiti S, Maffulli N. Thyroid hormones and tendon: current views and future perspectives. Concise review. Muscles Ligaments Tendons J. 2013;3(3):201-3.

4. Klatte-Schulz F, Pauly S, Scheibel M, Greiner S, Gerhardt C, Schmidmaier G, et al. Influence of age on the cell biological characteristics and the stimulation potential of male human tenocyte-like cells. Eur Cell Mater. 2012;24:74-89.

5. Loppini M, Maffulli N. Conservative management of tendinopathy: an evidence-based approach. Muscles Ligaments Tendons J. 2012;1(4):134-7.

6. Rutjes $A W$, Jüni $P$, da Costa BR, Trelle $S$, Nüesch $E$, Reichenbach $S$. Viscosupplementation for osteoarthitis of the knee: a systematic review and meta-analysis. Ann Intern Med. 2012;157(3):180-91.

7. Abate M, Schiavone C, Salini V. The use of hyaluronic acid after tendon surgery and in tendinopathies. Biomed Res Int. 2014;2014:783632.

8. Giai Via A, De Cupis M, Spoliti M, Oliva F. Clinical and biological aspects of rotator cuff tears. Muscles Ligaments Tendons J. 2014;3(4):359.

9. Yuan J, Wang MX, Murrell GA. Cell death and tendinopathy. Clin Sports Med. 2003;22(4):693-701.

10. Benson RT, McDonnell SM, Knowles HJ, Rees JL, Carr AJ, Hulley PA Tendinopathy and tears of the rotator cuff are associated with hypoxia and apoptosis. J Bone Joint Surg Br. 2010;92(3):448-53.

11. Meyer K. Chemical structure of hyaluronic acid. Fed Proc. 1958;17(4):1075-7.

12. Melrose J, Numata $Y$, Ghosh P. Biotinylated hyaluronan: a versatile and highly sensitive probe capable of detecting nanogram levels of hyaluronan binding proteins (hyaladherins) on electroblots by a novel affinity detection procedure. Electrophoresis. 1996;17(1):205.

13. Chen WY, Grant ME, Schor AM, Schor SL. Differences between adult and fetal fibroblasts in the regulation of hyaluronate synthesis: correlation with migratory activity. J Cell Sci. 1989;94(Pt 3):577-84.

14. Klein ES, Asculai SS, Ben-Ari GY. Effects of hyaluronic acid on fibroblast behavior in peritoneal injury. J Surg Res. 1996;61(2):473-6.

15. Hall $\mathrm{CL}$, Wang $\mathrm{C}$, Lange LA, Turley EA. Hyaluronan and the hyaluronan receptor RHAMM promote focal adhesion turnover and transient tyrosine kinase activity. J Cell Biol. 1994;126(2):575-88.

16. Wiig M, Abrahamsson SO, Lundborg G. Effects of hyaluronan on cell proliferation and collagen synthesis: a study of rabbit flexor tendons in vitro. J Hand Surg Am. 1996;21(4):599-604.

17. Bernard E, Hornebeck W, Robert L. Effect of hyaluronan on the elastase-type activity of human skin fibroblasts. Cell Biol Int. 1994;18(10):967-71.

18. Matuoka K, Namba M, Mitsui Y. Hyaluronate synthetase inhibition by normal and transformed human fibroblasts during growth reduction. J Cell Biol. 1987;104(4):1105-15.

19. Dean BJ, Snelling SJ, Dakin SG, Murphy RJ, Javaid MK, Carr AJ. Differences in glutamate receptors and inflammatory cell numbers are associated with the resolution of pain in human rotator cuff tendinopathy. Arthritis Res Ther. 2015;17:176.

20. Oliva F, Berardi AC, Misiti S, Verga Falzacappa C, lacone A, Maffulli N. Thyroid hormones enhance growth and counteract apoptosis in human tenocytes isolated from rotator cuff tendons. Cell Death Disease. 2013;4:e705.

21. Yao L, Bestwick CS, Bestwick LA, Maffulli N, Aspden RM. Phenotypic drift in human tenocyte culture. Tissue Eng. 2006;12(7):1843-9.

22. Yuan J, Murrell GA, Trickett A, Wang MX. Involvement of cytochome c release and caspase- 3 activation in the oxidative stress-induced apoptosis in human tendon fibroblasts. Biochimica et Biophysica Acta. 2003;1641(1):35-41.

23. Berardi AC, Oliva F, Berardocco M, la Rovere M, Accorsi P, Maffulli N. Thyroid hormones increase collagen type land cartilage oligomeric matrix protein (COMP) expression in vitro human tenocytes. Muscles Ligaments Tendons J. 2014;4(3):285-91.

24. Hanna S, Khalil B, Nasrallah A, Saykali BA, Sobh R, Nasser S, et al. StarD13 is a tumor suppressor in breast cancer that regulates cell motility and invasion. Int J Oncol. 2014;44(5):1499-511.

25. Evanko SP, Tammi MI, Tammi RH, Wight TN. Hyaluronan-dependent pericellular matrix. Adv Drug Deliv Rev. 2007;59(13):1351-65.

26. Karna E, Miltyk W, Surazyński A, Pałka JA. Protective effect of hyaluronic acid on interleukin-1-induced deregulation of beta1-integrin and insulin-like growth factor-I receptor signaling and collagen biosynthesis in cultured human chondrocytes. Mol Cell Biochem. 2008;308(1-2):57-64.

27. Oliva F, Gatti S, Porcellini G, Forsyth NR, Maffulli N. Growth factors and tendon healing. Med Sport Sci. 2012;57:53-64.

28. Maffulli N, Ewen SW, Waterston SW, Reaper J, Barrass V. Tenocytes from ruptured and tendinopathic achilles tendons produce greater quantities of 
type III collagen than tenocytes from normal achilles tendons. An in vitro model of human tendon healing. Am J Sports Med. 2000;28(4):499-505.

29. Yamada T, Gotoh M, Nakama K, Mitsui Y, Higuchi F, Nagata K. Effects of hyaluronan on cell proliferation and mRNA expression of procollagens alpha 1 (I) and alpha 1 (III) in tendon-derived fibroblasts from patients with rotator cuff disease: an in vitro study. Am J Sports Med. 2007;35(11):1870-6.

Submit your next manuscript to BioMed Central and take full advantage of:

- Convenient online submission

- Thorough peer review

- No space constraints or color figure charges

- Immediate publication on acceptance

- Inclusion in PubMed, CAS, Scopus and Google Scholar

- Research which is freely available for redistribution 